\title{
Insights of phytoconstituents and pharmacology activities of Salacca plants
}

\author{
Abdurahman Ridho ${ }^{1,2^{*}}$, Nasrul Wathoni ${ }^{3}$, Anas Subarnas ${ }^{2}$, Jutti Levita ${ }^{2}$ \\ ${ }^{1}$ Master Program of Pharmacy, Faculty of Pharmacy, Universitas Padjadjaran, Sumedang, Indonesia. \\ ${ }^{2}$ Department of Pharmacology and Clinical Pharmacy, Faculty of Pharmacy, Universitas Padjadjaran, Sumedang, Indonesia. \\ ${ }^{3}$ Department of Pharmaceutical and Technology Formulation, Universitas Padjadjaran, Sumedang, Indonesia.
}

\section{ARTICLE INFO \\ Received on: 26/06/2019 \\ Accepted on: 11/08/2019 \\ Available online: 05/10/2019}

\section{Key words:}

Antioxidant, cancer cell,

immune system, skin

whitening.

\begin{abstract}
In the last 20 years, plant-based therapy had become the world's attention. Our country Indonesia is popular in its megabiodiversity, among which is Salacca zalacca Gaert. (Voss.), or salak. The fruit of this plant is generally utilized as pickles, chips, etc. However, its benefits for health remain unexplored. Library searches using PubMed, Google Scholar, Science Direct, and Google resulted that $S$. zalacca, which contains flavonoids, alkaloids, terpenoids, and sitosterols exerts various pharmacology activities, e.g., antioxidant, cholesterol reducer, antidiabetic, skin whitening, antihyperuricemia, antibacterial, immune system enhancer, cancer cell growth inhibitor, and adsorbent.
\end{abstract}

\section{INTRODUCTION}

Treatment of diseases using natural ingredients begins to be popular and furthermore, becomes the world's attention. World Health Organization (WHO) states that $65 \%$ of treatment is carried out by people in developed and developing countries using natural materials (Republik Indonesia, 2007). It was estimated that $25 \%$ of medicinal products were made of empirically used plants (WHO, 2013).

Indonesia is a country which is abundant in plant biodiversity as supported by its tropical geographic conditions (located between two continents and two oceans). Salak [Salacca zalacca Gaert. (Voss.)] is a native plant whose fruit is the most favorable and generally utilized as dried fruit, pickles, chips, canned fruit in syrup, etc., (Zaini et al., 2013). Some mixtures for medicine in Indonesia consist of salacca fruit, seeds, and bark (Joshua and Sinuraya, 2019). Salacca fruit is often called snake fruit because of its dry and flaky peels which resemble snake skin (Aralas et al., 2009).

\section{${ }^{*}$ Corresponding Author}

Abdurahman Ridho, Master Program of Pharmacy, Faculty of Pharmacy, Universitas Padjadjaran, Jl. Raya Bandung-Sumedang km 21 Sumedang, West Java, Indonesia. E-mail: abdurahmanridho2@gmail.com
However, its benefits for health remain questionable; therefore, this review article will give insights into the botanical aspects, phytochemicals, and pharmacological activities of $S$. zalacca Gaert. (Voss.).

\section{METHODS}

This review is based on the literature obtained from the Google Scholar database using the keywords "Salacca" AND "Snake Fruit" AND "Antioxidant"; PubMed using keywords salacca [All Fields] AND ("antioxidants" [Pharmacological Action] OR "antioxidants" [MeSH Terms] OR "antioxidants" [All Fields] OR "antioxidant" [All Fields]) AND activities [All Fields]; Science Direct using keywords "Salacca" AND "Snake fruit" AND "Antioxidant" AND "Toxicity". The following exclusion criteria were applied: articles $<2,000$ and unrelated article. The flowchart of the literature search can be seen in Figure 1.

\section{BOTANICAL ASPECTS}

\section{Origin and botanical classification}

Salacca is a species of the palm tree (Arecaceae) native to Java and Sumatra in Indonesia. It contains dietary fiber and carbohydrates that are good for the body (Chareoansiri et al., 
2009). The taxonomy of salacca plants is (Cronquist, 1981) as follows:

$\begin{array}{ll}\text { Kingdom } & \text { : Plantae } \\ \text { Division } & \text { : Spermatophyta } \\ \text { Subdivision } & \text { : Angiospermae } \\ \text { Class } & \text { : Monocotyledoneae } \\ \text { Order } & \text { : Palmae } \\ \text { Family } & \text { : Palmaceae or Arecaceae } \\ \text { Genus } & \text { : Salacca } \\ \text { Species } & \text { : Salacca zalacca (Gaert.) Voss. } \\ \text { Synonym } & \text { : Salacca edulis Reinw. }\end{array}$

Parts of the salacca plants can be seen in Figure 2 (Naharudin, 2019).

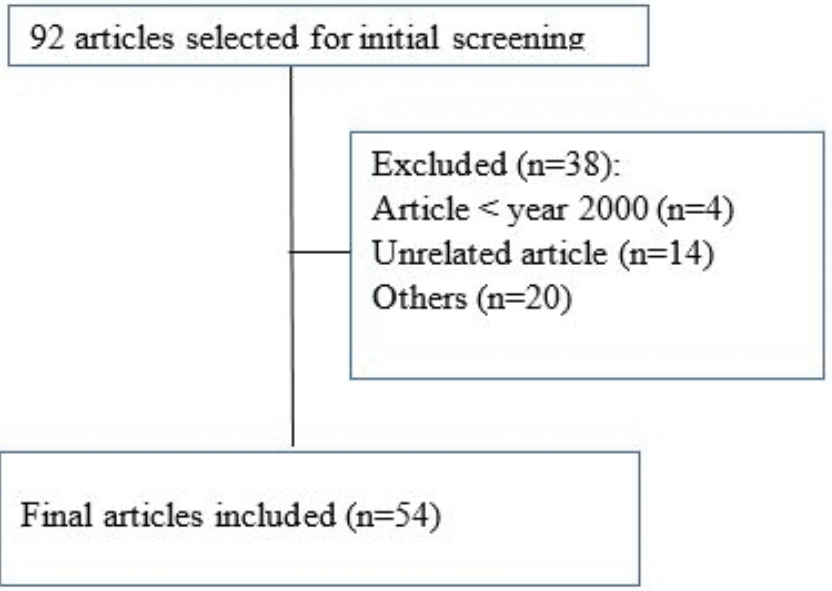

Figure 1. Flow chart of the reference search.

\section{Morphology and structure}

Salacca plant grows with thorns and its height can reach $6 \mathrm{~m}$. This plant can be productive for 50 years. They grow at low altitudes and high humidity. The trunk is large and pinnate with shiny dark green leaves. The fruit, oval in shape, assembled in groups at the base of the tree. The seed is dark brown segmented in the fruit (Zaini et al., 2013). Raw fruit, which has a sharp, bitter taste due to its tannic acid content, is usually prepared for pickles. However, the ripe fruit is sweet and has a pleasant aroma (Horn et al., 2009).

\section{NUTRITIONAL CONTENTS}

Salacca fruit, like other exotic fruits, contains vitamins, minerals, fiber, and sugar which are needed for daily needs in overcoming various types of diseases (Dembitsky et al., 2011). The proximate analysis of $100 \mathrm{~g}$ of zalacca resulted in sucrose $(7.6 \%)$, fructose $(5.9 \%)$, fructose $(3.9 \%)$, total sugar $(17.4 \%)$, soluble dietary fiber $(0.3 \%)$, insoluble dietary fiber $(1.4 \%)$, water $(80 \%)$, calories $(77 \mathrm{kcal})$, protein $(0.7 \%)$, ash $(0.6 \%)$, and fat $(0.1 \%)$. The contents of vitamins and minerals in $1 \mathrm{~kg}$ of the salacca fruit are ascorbic acid $(400 \mathrm{mg})$, carotene $(5 \mathrm{mg})$, thiamine $(20 \mathrm{mg})$, niacin $(240 \mathrm{mg})$, riboflavin $(0.8 \mathrm{mg})$ and folate $(6 \mathrm{mg})$, phosphorus $(1.161 \mathrm{mg})$, potassium $(11.339 \mathrm{mg})$, calcium $(220$ $\mathrm{mg}$ ), magnesium (607 mg), sodium (231 mg), iron (12.0 mg), manganese $(10.4 \mathrm{mg})$, copper $(3.36 \mathrm{mg})$, zinc $(10.4 \mathrm{mg})$, boron (5.07 mg), and sulfur (5.07 mg) (Chew et al., 2012; Gorinstein et al., 2009; Janick and Paull, 2008).

\section{Phytoconstituents}

NMR study of the dichloromethane extract of Salacca wallichiana Mart. revealed the presence of monogalactosyl diacylglycerols, $\beta$-sitosteryl-3 $\beta$-glucopyranoside- $6 \phi$-O-ester fatty acid, $\beta$-cytosterol, and triacylglycerol in the fruit peels, whereas in

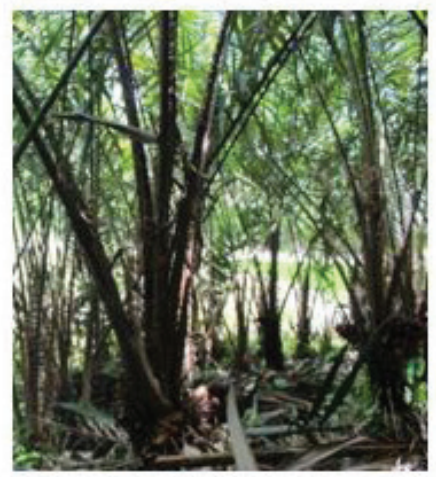

Tree

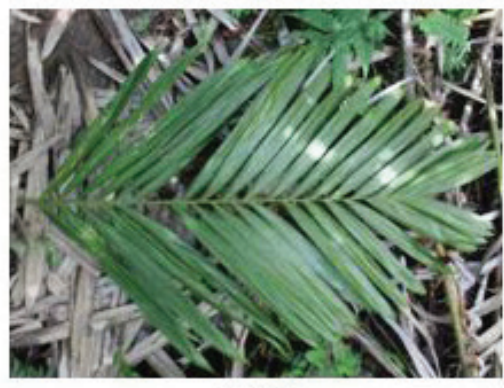

Leaves

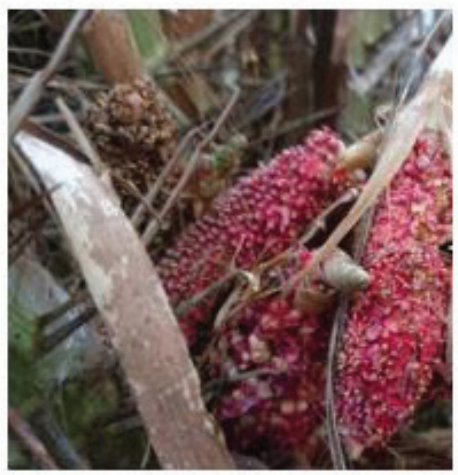

Male Flower

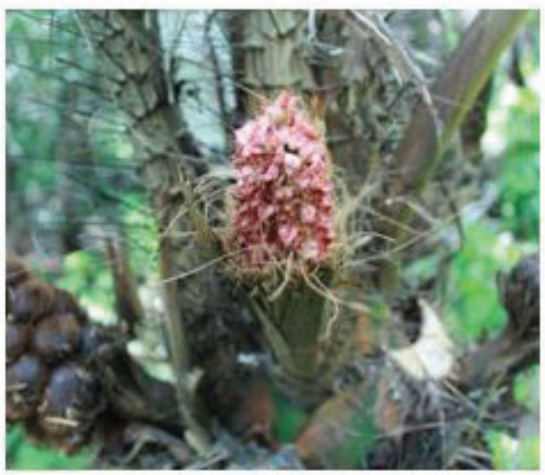

Female Flower

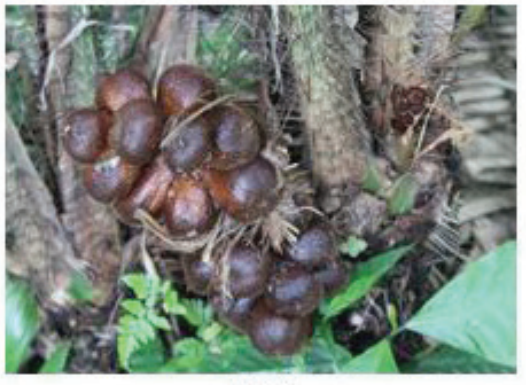

Fruit

Figure 2. Parts of salacca plants. 
the roots, several compounds, e.g., $\beta$-sitosterol and stigmasterol, had been reported. Moreover, $\beta$-cytosteryl-3 $\beta$-glucopyranoside$6 \phi$-O-ester fatty acids, triacylglycerol, and linoleic acid had been isolated from the seeds (Ragasa et al., 2016; Suica-Bunghez et al., 2016). Polyphenolic compounds and vitamin $\mathrm{C}$ were also reported to be significantly abundant in salacca fruit (Gorinstein et al., 2011).

The pleasant aroma of salacca fruit is generated by the combination of several phytochemicals; however, methyl esters of pentanoic acid (e.g., 3-methylpentanoate, methyl-3methylpentanoate, methyl-3-methyl-2-pentanoate) and butanoic acid (e.g., methyl-3-methyl-2-butanoate and 2-methylbutanoate) are considered responsible for this characteristic odor. Other aromatic compounds, e.g., 2,5-dimethyl-4-hydroxy-3[2]furanone, methyl dihydrojasmonate, and isoeugenol might also contribute to the overall aroma of salacca fruit (Wijaya et al., 2005). These methyl esters of carboxylic acids are also responsible for the sweet aroma of other salacca species, e.g., Salacca edulis Reinw Cv (Supriyadi et al., 2002). Moreover, 2-methylester-1h-pyrolle-4-carboxylic acid compound has reported its presence in the ethylacetate extract of salacca var. bongkok as well as flavonoids, alkaloids, tannins, terpenoids, and quinones (Afrianti et al., 2015). Epicatechin, proanthocyanidine, and chlorogenic acid were detected in the fruit extract by high-performance liquid chromatography (Shui, 2005). Compounds elucidated from salacca fruit is summarized in Table 1.

\section{PHARMACOLOGY ACTIVITIES}

\section{Antioxidant}

Salacca fruit extract was reported possessing a high antioxidant activity by scavenging DPPH free radical and/ or reducing ferric ion in plasma (Afrianti et al., 2010; Aralas, 2009; Gorinstein et al., 2009; Kanlayavattanakul et al., 2013; Suica-Bunghez et al., 2016; Zubaidah et al., 2017), and reducing ABTS (2,2-azinobis (3-ethylbenzothiazoline-6-sulfonic acid). Furthermore, other study indicated that the ethanol extract and fractions of salacca fruit contained phenols, flavonoids, and tannins. The strongest antioxidant activity was shown by $100 \%$ methanol fraction $\left(\mathrm{IC}_{50}=110.16 \mu \mathrm{g} / \mathrm{ml}\right.$ ) (Werdyani et al., 2017). Salacca seed might be potential to be proposed as a local competitive coffee product due to its antioxidant activity $\left(\mathrm{IC}_{50}=\right.$ $9.37 \mathrm{mg} / \mathrm{ml})$. It has low caffeine $(0.207 \%)$, low fat $(2.95 \%)$, high carbohydrates $(80.98 \%)$, water $(6.24 \%)$, ash $(3.49 \%)$, and protein $(6.34 \%)$. However, the ethyl acetate fraction of $S$. edulis peels indicated the most potent antioxidant property $\left(\mathrm{DPPH}_{\mathrm{IC} 50}=2.932\right.$ $\pm 0.030 \mathrm{~g} / \mathrm{ml}, \mathrm{ABTS}_{\mathrm{IC} 50}=7.933 \pm 0.049 \mathrm{~g} / \mathrm{ml}$, and $\mathrm{FRAP}_{\mathrm{EC}}=$ $7844.44 \pm 40.734)$ (Dikta, 2015).

The $100 \%$ ethanol extract of salacca was reported containing higher phenolic level $(116.70 \pm 0.764 \mu \mathrm{g} / \mathrm{ml})$ and antioxidant activity $\left(\mathrm{IC}_{50}=49.45 \pm 3.87 \mu \mathrm{g} / \mathrm{ml}\right)$ compared to the $60 \%$ ethanol extract (Misra et al., 2018). High phenolic compounds in salacca fruit were also reported by other workers (Leontowicz et al., 2006). Other salacca cultivars, e.g., Nglumut, Bali, and Sumalee, also contained high phenolic compounds and vitamin C. Reducing the power of salacca Nglumut cultivar is significantly higher than that of Balinese or Pondoh cultivars (Gorinstein et al., 2009).
Table 1. Phytoconstituent of Salacca fruit.

\begin{tabular}{|c|c|c|}
\hline Part of plants & Compounds & References \\
\hline \multirow[t]{2}{*}{ Fruit pulp } & $3 \beta$-hydroxy-cytosterol & Priyatno et al., 2007 \\
\hline & $\begin{array}{l}\text { 2-methylester-1-H-pyrrole-4- } \\
\text { carboxylic acid }\end{array}$ & \\
\hline \multirow[t]{5}{*}{ Fruit pulp } & Anthocyanin & Gorinstein et al., 2011 \\
\hline & Polyphenols & \\
\hline & Tannin & \\
\hline & Flavanols & \\
\hline & Flavonoids & \\
\hline \multirow[t]{5}{*}{ Fruit pulp } & Alkaloid & Afrianti et al., 2015 \\
\hline & 3-hydroxystigmastan-5(6)-en & \\
\hline & Terpenoid & \\
\hline & $\begin{array}{l}\text { Pyrolle-2,4-dicarboxylic acid- } \\
\text { methyl ester }\end{array}$ & \\
\hline & Quinones & \\
\hline \multirow[t]{7}{*}{ Fruit pulp } & $\beta$-cytosterone & Ragasa et al., 2016 \\
\hline & $\begin{array}{l}\beta \text {-cytosteryl-3 } \beta \text {-glucopyranoside- } \\
6 \text { '-O-fatty acid ester }\end{array}$ & \\
\hline & Triacylglycerols female flower & \\
\hline & $\beta$-cytosterol roots & \\
\hline & Linoleic acid & \\
\hline & Stigmasterol & \\
\hline & Monogalactosyl diacylglycerols & \\
\hline \multirow[t]{6}{*}{ Peel } & Quercetin & Kanlayavattanakul et al., 2012 \\
\hline & Chlorogenic acid & \\
\hline & Gallic acid & \\
\hline & Ferulic acid & \\
\hline & Caffeic acid & \\
\hline & Rosmarinic acid & \\
\hline
\end{tabular}

\section{Cholesterol-lowering activity}

In vivo assay of salacca fruit and/or peel extract indicated a cholesterol-lowering activity (Dhaneswari et al., 2015; Leontowicz et al., 2006; Nuranti et al., 2014). Flavonoids are compounds that play an important role in reducing cholesterol levels in the blood by decreasing HMG-CoA enzyme activity and increasing cholesterol activity 7- $\alpha$ hydroxylase (Honda et al., 2013).

Heart histopathologic of white rats treated with Salacca edulis extract indicated less fat infiltration compared to that of the control group (Hardjana et al., 2016).

\section{Antidiabetic activity}

Salacca fruit peel extract, which contains alkaloids, flavonoids, saponins, steroids and triterpenoids, phenolic hydroquinone, tannins, and cinnamic acid, indicated antidiabetic activity (Sahputra, 2008). Ferulic acid and proline found in the salacca fruit peel could stimulate the formation of collagen and elastin, while cinnamic acid derivates increase cell regeneration, and arginine stimulates cell division as well as increases protein biosynthesis. Moreover, pterostilbene could lower blood sugar level (Rohaeti et al., 2017).

All salacca vinegars were capable of reducing blood sugar (from $25.1 \%$ to $62 \%$ ) and low density lipoprotein (from 9.5 to 14.8 
$\mathrm{mg} / \mathrm{dl}$ ), triglyceride (from 58.3 to $69.5 \mathrm{mg} / \mathrm{dl}$ ), malondialdehyde (from 1.1 to $2.2 \mathrm{mg} / \mathrm{dl}$ ), and total cholesterol (from 56.3 to $70.5 \mathrm{mg}$ / dl) as well as increasing high density lipoprotein on streptozotocin (STZ)-induced diabetic Wistar rats (from 52.3 to $60 \mathrm{mg} / \mathrm{dl}$ ). Various salacca vinegars were also capable of regenerating pancreatic cells. Nevertheless, the ability of Swaru salacca vinegar to manage hyperglycemia and dyslipidemia appeared to be superior to other salacca vinegars. Swaru salacca vinegar is a potential therapeutic agent to manage hyperglycemia and dyslipidemia on STZ-induced diabetic rats (Zubaidah et al., 2014; 2017).

\section{Antimicrobe}

Extract of Salacca edulis, which contains tannins, flavonoids, and alkaloids, has inhibited the growth of E. coli. The highest inhibition zone was obtained at a concentration of $100 \%$ (average diameter $18.783 \mathrm{~mm}$ ), although, it was smaller than that of positive control (average diameter $31.367 \mathrm{~mm}$ ) (Nurina et al., 2014).

\section{Immunostimulants}

Salacca peel extract showed high stimulation of the immune system. It enhanced the phagocytotic activity of murine macrophage-like J774.1 cell. Production of cytokine such as tumor necrosis factor (TNF)-alpha and interleukin (IL)-6 was also stimulated (Wijanarti et al., 2016; 2017).

\section{Antihyperusemic activity}

Two compounds isolated from salacca fruit, i.e., 3 $\beta$-hydroxy-sitosterol and 2-methylester-1-H-pyrrole-4-carboxylic acid indicated good inhibitory activity against xanthine oxidase $\left(\mathrm{IC}_{50} 48.86 \mu \mathrm{g} / \mathrm{ml}\right.$ ) (Lasekan and Abbas, 2012). The ethanol extract of salacca fruit also significantly decreased serum uric acid levels compared to the control group (Priyatno et al., 2012).

\section{Anticancer and cytotoxic activity}

Salacca fruit has been proven in exhibiting the growth of human Hepoma (HepG2), human colon cancer (HT-29), human lung cancer (A549), and human breast cancer (MCF-7) (Li et al., 2013). Moreover, pyrolle-2,4-dicarboxylic acid-methyl ester and 3-hydroxystigmastan-5(6)-en ( $\beta$-sitosterol) isolated from $S$. edulis fruit showed cytotoxic activity against MCF-7 and T47D cell lines (Gorinstein et al., 2011). Brine shrimp lethality test of the liquid smoke of salacca seed showed toxicity towards Artemia salina Leach larvae $\left(\mathrm{LC}_{50}=23.44 \mathrm{ppm}\right)$ (Wagania et al., 2018).

Additionally, salacca fruit extract demonstrated cytotoxicity against Vero cells and normal human fibroblast cell line that was correlated with its antioxidant capacity (Kanlayavattanakul et al., 2013).

\section{CONCLUSION AND FUTURE PERSPECTIVES}

Salacca fruit, which is cultivated and consumed in tropical countries, has been reported as a good source of antioxidant compounds. Salacca contains flavonoids, alkaloids, tannins, terpenoids, sitosterols, carboxylic acids, and its methyl esters, and quinones. Salacca exhibits antioxidant activity and could reduce blood cholesterol level. It has also potential as antidiabetic, antihyperuricemia, antibacterial, enhances the immune system, and inhibits the growth of cancer cells. This tropical fruit needs further exploration, particularly the mechanism of its biological activity, to be proposed as a nutritional beverage.

\section{ACKNOWLEDGMENT}

The authors would like to thank the Rector of Universitas Padjadjaran via Internal Research Grant of Universitas Padjadjaran 2019.

\section{CONFLICT OF INTEREST} interest.

The authors declared that they have no conflict of

\section{REFERENCES}

Afrianti LH, Sukandar EY, Ibrahim S, Adnyana IK. Studies on 2-methylester-1-h-pyrolle-4-carboxylic acid compound in ethylacetate extract of snake fruit variety bongkok as antioxidant and anthyperuricemic. J Food Technol Ind, 2010; 21(1):66-72.

Afrianti LH, Widjaja WP, Suliasih N, Widowati W, Fauziah N, Maesaroh M. Anticancer activity of 3-hydroxystigmastan- 5(6)-en ( $\beta$-sitosterol) compound from Salacca edulis Reinw variety Bongkok in MCF-7 and T47D cell line. J Adv Agric Technol, 2015; 2(2):129-33.

Aralas S. Antioxidant properties of selected salak (Salacca zalacca) varieties in Sabah, Malaysia. Nutr Food Sci, 2009; 39(3):243-50.

Chareoansiri R, Kongkachuichai R. Sugar profiles and soluble and insoluble dietary fiber contents of fruits in Thailand markets. Int J Food Sci Nutr, 2009; 60:126-39.

Chew SC, Loh SP, Khor GL. Determination of folate content in commonly consumed Malaysian foods. Int Food Rese J, 2012; 19(1): $189-97$.

Cronquist A. An integrated system of classification of flowering plants. Columbia University Press, New York, pp 248-50, 1981.

Dembitsky V M, Poovarodom S, Leontowicz H, Leontowicz M, Vearasilp S, Trakhtenberg S. The multiple nutrition properties of some exotic fruits: biological activity and active metabolites. Food Res Int, 2011; 44(7):1671-701.

Dhaneswari P, Sula CG, Ulima Z, Andriana P. Pemanfaatan Pektin yang Diisolasi dari Kulit dan Buah Salak (Salacca Edulis Reinw) Dalam Uji In Vivo Penurunan Kadar Kolesterol dan Glukosa Darah Pada Tikus Jantan Galur Wistar. KHAZANAH, 2015; 7(2).

Dikta, PGA. Produksi Kelompok Tani Abian Salak Desa Sibetan. Kelompok Tani Abian, 2015; 1(2):123-33 [ONLINE]. Available via http:// jurnal.undhirabali.ac.id/index.php/virgin/article/view/60/59 (Accessed 12 May 2019).

Gorinstein S, Haruenkit R, Poovarodom S, Park YS, Vearasilp S Antioxidant properties and bioactive constituents of some rare exotic Thai fruits and camparison with conventional fruits in vivo and in vitro studies. Food Research International, 2011; 44(7):2222-32.

Gorinstein S, Haruenkit R, Poovarodom S, Park YS, Vearasilp $\mathrm{S}$. The Comparative characteristics of snake and kiwi fruits. Food Chem Toxicol, 2009; 47:1884-91.

Hardjana T, Kartika RP, Tutik R. Snake fruit potent (Salacca edulis R.) as hypolypidemic supplement from the view of heart hystopathology and fat low diet of mice hepar. J Sains Dasar, 2016; 5(2):94-106.

Honda K, Saneyasu T, Hasegawa S, Tominaga H, Yokota S, Kamisoyama $\mathrm{H}$. Effect of licorice flavonoid oil on cholesterol metabolism in high fat diet rats. Biosci Biotech Biochem, 2013; 77(6):1326-8.

Horn JW, Fisher JB, Tomlinson PB, Lewis CE, Yer LK. Evolution of lamina anatomy in the palm family (Arecaceae). Am J Bot, 2009; 96(8):1462-86

Janick J, Paull RE. Salacca zalacca-salak. In: The encyclopedia of fruit \& nuts. 2nd edition, Cambrige University Press, UK, pp 153-6, 2008.

Joshua, Sinuraya RK. Review Jurnal: Keanekaragaman Aktivitas Farmakologi Tanaman Salak (Salacca zalacca). Farmaka, 2018; 16(1):99107. 
Kanlayavattanakul M, Lourith N, Ospondpant D, Ruktanonchai U, Pongpunyayuen S, Chansriniyom C. Salak plum peel extract as a safe and efficient antioxidant appraisal for Cosmetics. Biosci Biotechnol Biochem, 2013; 77(5):1068-74.

Lasekan O, Abbas KA. Distinctive exotic flavor and aroma compounds of some exotic tropical fruits and berries: a review. Crit Rev Food Sci Nutr, 2012; 52(8):726-35.

Leontowicz, H. Bioactive properties of Snake fruit (Salacca edulis Reinw) and Mangosteen (Garcinia mangostana) and their influence on plasma lipid profile and antioxidant activity in rats fed cholesterol. Eur Food Res Technol, 2006; 223(5):697-703.

Li F, Li S, Li HB, Deng GF, Ling WH, Wu S, Chen F. Antiproliferative activity of peels, pulps and seeds of 61 fruits. J Funct Foods, 2013; 5(3):1298-309.

Misra AK, Varma SK, Kumar R. Anti-inflammatory effect of an extract of Agave americana on experimental animals. Pharmacogn Res, $2018 ; 24-30$

Nuranti N, Nadya, Fitraningsih SP, Lestari F. Uji Aktivitas Anti hiperkolesterolemia Ekstrak Etanol Kulit Buah Salak (Salacca zalacca (Gaertner.) Voss) Terhadap Mencit Swiss Webster Jantan yang Diinduksi Diet Tinggi Lemak. Prosiding penelitian SPeSIA Unisiba, 2014; 468-74.

Nurina CIE, Samingan, Iswadi. Uji Antimikroba Ekstrak Buah Salak (Salacca edulis) terhadap bakteri Escherchia coli. Jurnal Biologi Edukasi, 2014; 12(6):19-23.

Naharudin P. Snake Fruit (Salak) explained-Salacca Zalacca Information \& Facts, 2019 [ONLINE]. Avaliable via https://thesnakefruit. $\mathrm{com} / \mathrm{blog} / \mathrm{snake}$-fruit-salak-explained-salacca-zalacca-information-facts/ (Accessed 29 July 2019).

Priyatno LHA, Sukandar EY, Ibrahim S, Adnyana IK Antihyperuricemic effect of ethanol extract of snake fruit (Salacca edulis Reinw) var. Bongkok on wistar male rat. J Food Sci Eng, 2012; 2:271-6.

Priyatno LHA, Sukandar EY, Ibrahim S, Adnyana IK. Xanthine oxidase inhibitor activity of terpenoid and pyrrole compounds isolated from snake fruit (Salacca edulis Reinw.) cv. Bongkok. J Appl Sci, 2007; 7(20):3127-30.

Ragasa CY, Ting JU, Ramones MV, Carmen MST, Lerom RR, Linis VC. Chemical constituents of Salacca wallichiana mart. Int J Curr Pharm Rev Res, 2016; 7(4):186-9.

Republik Indonesia. Keputusan Menteri Kesehatan Republik Indonesia Nomor 381/MENKES/SK/III/2007 tentang Kebijakan Obat Tradisional Nasional, Sekretariat Negara, Jakarta, p. Republik Indonesia. Keputusan Menteri Kesehatan Republik Indonesia Nomor 381/MENKES/ SK/III/2007 tentang Kebijakan Obat Tradisional Nasional, Sekretariat Negara, Jakarta, p 9, 2007

Rohaeti E, Fauzi MR, Batubara, I. Inhibition of $\alpha$-glucosidase, total phenolic contetnt and flavonoid content on skin fruit and flesh extract some varietes of snake fruits. IOP Publishing, Bristol, UK,p 58, 2017.

Sahputra, FM. Potensi Ekstrak Kulit dan Daging Buah Salak sebagai Antidiabetes [Skripsi]. Institut Pertanian Bogor, Bogor, Indonesia, p 18, 2018.

Shui G, Leong LP. Screening and Identification of Antioxidant in Biological Samples Using High Performance Liquid ChromatographyMass Spectrometry and Its Application on Salacca edulis Reinw. J Agric Food Chem, 2005; 53(4):880-6.
Suica-Bunghez, I. R. Antioxidant activity and phytochemical compounds of snake fruit (Salacca Zalacca). IOP Conf Ser Mater Sci Eng, $2016 ; 133(1)$

Supriyadi, Suhardi, Suzuki M, Yoshida K, Muto T, Fujita A. Changes in the volatile compounds and in the chemical and physical properties of snake fruit (Salacca edulis Reinw) Cv. pondoh during maturation. J Agric Food Chem, 2002; 50:7627-33.

Wagania, L. Pyrolisis of salak seed (Salacca zallaca) and toxicity test of its liquid smoke to the mortality of Artemia salina Leach larvae. Int J Appl Eng Res, 2018; 13(12):10593-7.

Werdyani S, Jumaryatno P, Khasanah N. Antioxidant activity of ethanolic extract and fraction of salak fruit seeds (Salacca Zalacca (Gaertn.) Voss.) using Dpph (2,2-Diphenyl-1-Picrylhydrazyl) method. Jurnal Eksakta, 2017; 17(2):137-46.

WHO. WHO traditional medicine tragedy, 2013 [ONLINE]. Available via http://www.who.int/traditionalcomplementaryintegrative medicine/en/ (Accessed 10 April 2019).

Wijanarti S, Putra ABN, Nishi K. Immunostimulatory activity of snake fruit (Salacca edulis Reinw.) cultivar Pondoh Hitam extract on the activation of macrophages in vitro. AIP Conference Proceedings 1840, pp $1-9,2017$.

Wijaya C.H. Identification of potent odorants in differen cultivars of snake chromatography-olfactometry. J Agric Food Chem, 2005; 53(5):1637-41.

Zaini NAM, Osman A, Hamid AA, Ebrahimpour A, Saari N Purification and characterization of membrane-bound polyphenoloxidase (mPPO) from snake fruit [Salacca zalacca (Gaertn.) Voss]. J Food Chem, 2013; 136(2):407-14.

Zubaidah E, Ichromasari DY, Mandasari OK. Effect of Salacca vinegar var. suwaru on lipid profile diabetic rats. J Food Nutr Sci, 2014; 5(9):743-8.

Zubaidah E, Putri WDR, Puspitasari T, Kalsum U, Dianawati D. The effectiveness of various Salacca vinegars as therapeutic agent for management of hyperglycemia and dyslipidemia on diabetic rats. Int J Food Sci, 2017; 1-7.

How to cite this article:

Ridho A, Wathoni N, Subarnas A, Levita J. Insights of phytoconstituents and pharmacology activities of Salacca plants. J Appl Pharm Sci, 2019; 9(10):120-124. 